\title{
BIOMETRIC METHOD OF AGE ESTIMATION: DEVELOPMENT AND EFFICIENCY, IN CASES OF PATHOLOGIES OF TEETH HARD TISSUES
}

\author{
${ }^{1} \mathrm{M}$. Yu. Goncharuk-Khomyn, ${ }^{2}$ Kh. V. Pohoretska, ${ }^{2} \mathrm{~L}$. O. Patskan \\ ${ }^{1}$ UZHHOROD NATIONAL UNIVERSITY, UZHHOROD, UKRAINE \\ 2I. HORBACHEVSKY TERNOPIL STATE MEDICAL UNIVERSITY, TERNOPIL, UKRAINE
}

Background. The physiological changes of tooth are the criteria used in evaluation of regressive formula by Kvaal et al. age estimation technique. But in cases of abnormal occlusion, abnormal chewing habits, bruxism, abrasive factors or structural defects of teeth the intensity of tooth aging accelerates.

Objective. The aim of the research was to define the options of age estimation according to dental state of individuals with pathological attrition.

Methods. 108 panoramic $x$-ray photos of patients with pathological attrition of teeth were chosen by a randomized selection (49 males and 59 females). All photos were made by means of Planmeca PROMAX orthopantomograph. Nine measurements were made for each tooth: the tooth length, pulp length, root length, root width and pulp width at three different levels: cement-enamel junction (level $A$, beginning of root), one-quarter of root length from a cement-enamel junction (level B), and mid-root (level C). Due to these measurements, a number of ratios were calculated in accordance with Kvaal et al. method.

Results. The errors that reached $27 \pm 8.4$ years were found when evaluating the dental age using primary coefficients of equations suggested by the authors of the method used. By means of mathematical analyses, principal component regression method as well, the correlation coefficient of Pearson and method of combining linear regression due to the tooth changes in cases of pathological attrition (lowering level of occlusal surface, dystrophy of pulp structures and deposition of tertiary reparative dentine) by regression analysis, the modified formulas for age estimation using radiographic technique were found. Modified coefficients decreased the error to $13 \pm 0.8$ years, which was relative to the real age upto nearly $42-48 \%$ compared to the primary coefficients of equations for pathological attrition.

Conclusions. Age estimation technique can be improved taking into account morphological changes in pathological attrition and the calculated coefficients make it possible to expand the circle of person's age which needs to be found.

KEY WORDS: age estimation; Kvaal method; pathological attrition; regression analyses; reparative dentine deposition.

\section{Introduction}

Estimation of biological age of a person is significant in forensic science, especially for comparative and reconstructive identification antemortem and postmortem as recommended by Interpol/ICPO (International Criminal Police Organization) and FBI (Federal Bureau of Investigation). Justice bodies in an ethnically heterogeneous society use the results of age estimation by dental status where age indicators affect the need of socio-vulnerable persons, illegal immigrants and children and allow benefiting from the state budget; it also

Corresponding author: Myroslav Goncharuk-Khomyn, Department of Prosthetic Dentistry, Uzhhorod National University, 16/a Universytetska Str., Uzhhorod, Ukraine, 88000 Phone number: +380991212813

E-mail: myroslav.goncharuk-khomyn@uzhnu.edu.ua influences on level of criminal responsibility of persons with regard to age limit [1]. Age is the least variable and probably the most accurate determining parameter, since the aging process is the most independently reflected in changes of pulp and hard tissues of teeth than any other functional system of the body that is more vulnerable to the effects of pathologal features, constitution and physiological defects. Practical determination of the age of adults is possible using morphological techniques of Gustafson G. ("Age determination on teeth"), Bang G., Ramm E. ("Determination of age in humans from root dentine transparency") Johanson G. ("Age determination from teeth"), Maples W. R. ("An improved technique using dental histology for estimation of adult age"), 
and morphologically-radiographic techniques of Solheim T. ("A new method for dental age estimation in adults"), Kvaal S. I. et al ("Age estimation of adults from dental radiograph") [2-10]. The most rational method which excludes extraction of teeth and subjective grading of morphological indicators is Kvaal et al. technique, which involves calculating the ratio of length of crown and root to the length of pulp, width of root to the width of pulp in specifically designated areas, searches averages and uses standardized coefficients for the final result. However, this technique does not provide the effective use in cases of the presence of hard tissue lesions of teeth, pathological attrition is the most common. Attrition is a constant form of retrogressive changes in teeth, which involves lowering the level of occlusal surface in the amount related to the normal process of aging. The physiological loss of hard tissue caused by tooth-to-tooth contact in occlusion and mastification depends on diet, dentition, force of mastificatory muscles and chewing habits. Physiological attrition is proportional to the age of an individual as deposition of secondary dentine or pulp changes during lifetime [11-13]. The physiological changes of tooth are the criteria used in calculation of regressive formula by Kvaal et al. age estimation technique. But in cases of abnormal occlusion (crowding of teeth, malposed teeth, lesions of prosthetics treatment), abnormal chewing habits, bruxism, abrasive factors or structural defects in teeth take place the intensity of tooth aging increases. This process is pathological attrition. We have found out that in pathological attrition the occlusal level of teeth lowers in a few times faster in dependence of forces that influence. Formation of reparative tertiary dentine, closing volume of pulp chamber and dystrophy processes take place in pulp structure that is unusual for physiological attrition [14-20]. Due to all these factors and principles we have approbated primary method of Kvaal et al. age estimation technique and found modified regression formulas that approximate the calculation results with the real age.

\section{Methods}

108 panoramic $X$-rays photo of patients with pathological attrition of teeth were chosen by a randomized selection (49 males and 59 females). All photos were made by means of Planmeca PROMAX orthopantomograph [1415]. Using graphical redactor Adobe Photoshop
CS3 some teeth were cut from each panoramic photo: maxillary central incisor, lateral incisor and second premolar, mandibular later incisor, canine and first premolar, and all of them were positioned strongly on vertical axis. Nine measurements of each tooth were made: tooth length, pulp length, root length, root width and pulp width at three different levels: cementenamel junction - (level A, beginning of root), one-quarter of the root length from the cement-enamel junction (level B), and mid-root (level C) [10]. All measurements were performed by means of Measurement tool in Adobe Photoshop CS3 mainly in pixels and then converted into millimeters. For each value 7 measurements were made and for further calculation the average means were estimated (Table 1).

From the measurements, a number of ratios were calculated in accordance with Kvaal et al.: $\mathrm{P}$ - the ratio of pulp length to root length; $T$ the ratio of tooth length to root length; $R$ - the ratio of pulp length to tooth length; $A$ - the ratio of width of pulp to root at level A; B - the ratio of width of pulp to root at level $B ; C$ - the ratio of width of pulp to root at level C; M - the mean values of all ratios; $W$ - the mean value of width ratios from levels $B$ and $C ; L$ - the mean value of length ratios $P$ and $R$; W-L - the difference between $W$ and $L$ [10]. All ratios were calculated using standard Microsoft Office program package Microsoft Office Excel. The mean of all ratios $(M)$ was used as the first predictor, while the difference between the mean of the 2 width ratios and the mean of the 2 length ratios $(W-L)$ was used as the second predictor. The results of estimated age differ significantly from real age and reach the error up to nearly $48 \%$. Using correlation coefficient and principal component regression method it was established that the strongest correlation between age results of patients with pathological attrition and calculated ratios was evidenced between $R$ and further L, W, and also A (as the level closest to the centers of reparative dentine formation), which occurred because of significantly different level of tooth loss and closing volume of pulp chamber due to attrition (Table 2).

The statistical information was analyzed by means of Statystics Pro software and linear regression analysis, thus new modified coefficients for Kvaal et al. primary formulas were estimated (Table 3).

As a result, the error reached $13 \pm 0.9$ years and did not increase more. 
Table 1. Example of measurement of tooth specific indicators of patient with pathological attrition

\begin{tabular}{|c|c|c|c|c|}
\hline \multirow[b]{2}{*}{$\begin{array}{c}\text { Specific } \\
\text { parameters }\end{array}$} & \multirow[b]{2}{*}{$\begin{array}{l}\text { Base/repeat } \\
\text { measurements }\end{array}$} & \multicolumn{3}{|c|}{ Measurements and calculations } \\
\hline & & $\begin{array}{c}\text { Number } \\
\text { of measurements }\end{array}$ & $\begin{array}{l}\text { Mean } \\
(\mathrm{mm})\end{array}$ & $\begin{array}{l}\text { Difference } \\
\text { (mm) }\end{array}$ \\
\hline \multirow[t]{2}{*}{ Tooth length } & Main measurement & 7 & 22.07 & \multirow{2}{*}{0.03} \\
\hline & Repeated measurement & 7 & 22.10 & \\
\hline \multirow[t]{2}{*}{ Pulp length } & Main measurement & 7 & 17.02 & \multirow[b]{2}{*}{0.47} \\
\hline & Repeated measurement & 7 & 16.55 & \\
\hline \multirow[t]{2}{*}{ Root length } & Main measurement & 7 & 15.00 & \multirow{2}{*}{0.29} \\
\hline & Repeated measurement & 7 & 14.71 & \\
\hline \multirow[t]{2}{*}{ Pulp width $A$} & Main measurement & 7 & 0.82 & \multirow{2}{*}{0.01} \\
\hline & Repeated measurement & 7 & 0.81 & \\
\hline \multirow[t]{2}{*}{ Pulp width B } & Main measurement & 60 & 0.72 & \multirow{2}{*}{0.02} \\
\hline & Repeated measurement & 60 & 0.70 & \\
\hline \multirow[t]{2}{*}{ Pulp width C } & Main measurement & 60 & 0.39 & \multirow{2}{*}{0.01} \\
\hline & Repeated measurement & 60 & 0.40 & \\
\hline \multirow[t]{2}{*}{ Root width $A$} & Main measurement & 60 & 5.14 & \multirow{2}{*}{0.04} \\
\hline & Repeated measurement & 60 & 5.10 & \\
\hline \multirow[t]{2}{*}{ Root width B } & Main measurement & 60 & 4.36 & \multirow{2}{*}{0.07} \\
\hline & Repeated measurement & 60 & 4.29 & \\
\hline \multirow[t]{2}{*}{ Root width C } & Main measurement & 60 & 3.82 & \multirow{2}{*}{0.07} \\
\hline & Repeated measurement & 60 & 3.75 & \\
\hline
\end{tabular}

Table 2. Correlation between age of patients with pathological attrition and the ratios of measurements

\begin{tabular}{|c|c|c|c|c|c|c|}
\hline & $\begin{array}{c}\text { Upper central } \\
\text { incisor }\end{array}$ & $\begin{array}{c}\text { Upper lateral } \\
\text { incisor }\end{array}$ & $\begin{array}{c}\text { Upper second } \\
\text { premolar }\end{array}$ & $\begin{array}{c}\text { Lower lateral } \\
\text { incisor }\end{array}$ & $\begin{array}{c}\text { Lover } \\
\text { canine }\end{array}$ & $\begin{array}{c}\text { Lower first } \\
\text { premolar }\end{array}$ \\
\hline P & -0.11 & -0.08 & -0.16 & -0.15 & -0.07 & -0.49 \\
\hline T & -0.34 & -0.07 & -0.11 & -0.12 & -0.16 & -0.44 \\
\hline R & 0.24 & -0.14 & -0.16 & -0.12 & -0.04 & -0.28 \\
\hline A & -0.19 & -0.30 & -0.16 & -0.22 & -0.90 & -0.10 \\
\hline B & -0.30 & -0.20 & -0.16 & -0.32 & -0.14 & -0.20 \\
\hline C & -0.32 & -0.30 & -0.27 & -0.31 & -0.15 & -0.20 \\
\hline M & -0.31 & -0.26 & -0.21 & -0.34 & -0.17 & -0.39 \\
\hline L & -0.08 & -0.11 & -0.17 & -0.27 & -0.14 & -0.23 \\
\hline W-L & -0.39 & -0.14 & -0.08 & -0.30 & -0.02 & 0.21 \\
\hline
\end{tabular}

Table 3. Modified regression equations of patients with pathological attrition

\begin{tabular}{|l|l|c|c|}
\hline & \multicolumn{1}{|c|}{ Equation } & $\begin{array}{c}\text { R2 } \\
\text { (Coefficient of determination) }\end{array}$ & $\begin{array}{c}\text { Significant } \\
\text { predictors }\end{array}$ \\
\hline All six teeth & Age $=45.1+5.42 \mathrm{M}+3.76 \mathrm{~W}-\mathrm{L}$ & 0.21 & None \\
\hline Lower canine & Age $=77.1-84.1 \mathrm{M}-51.09 \mathrm{~W}-\mathrm{L}$ & 0.012 & None \\
\hline Lower lateral incisor & Age $=24.6+4.06 \mathrm{M}-19.01 \mathrm{~W}-\mathrm{L}$ & 0.04 & None \\
\hline Lower first premolar & Age $=-21.4+16.5 \mathrm{M}-36.1 \mathrm{~W}-\mathrm{L}$ & 0.356 & $\mathrm{M}$ and W-L \\
\hline Upper second premolar & Age $=125.6-84.02 \mathrm{M}+42.4 \mathrm{~W}-\mathrm{L}$ & 0.211 & $\mathrm{~W}-\mathrm{L}$ \\
\hline Upper lateral incisor & Age=35.11-16.5 M-38.1 W-L & 0.214 & None \\
\hline Upper central incisor & Age=35.6-76.8 M-56.3 W-L & 0.27 & $\mathrm{~W}-\mathrm{L}$ \\
\hline Upper three teeth & Age=30.14+14.7 M+2.10 W-L & 0.045 & $\mathrm{M}$ \\
\hline Lower three teeth & Age $=19.2+5.7 \mathrm{M}-12.18 \mathrm{~W}-\mathrm{L}$ & 0.051 & $\mathrm{~W}-\mathrm{L}$ \\
\hline
\end{tabular}

\section{Results}

The most significant correlation results between tooth and age were established in upper and lower incisors, and lower premolar. The lowest correlation was found at lower canine in patients with pathological attrition because of the level of influence of pathological attrition on different types of tooth. The Pearson correlation coefficients between chronological age and different ratios ( $P, T, R, A, B, C)$ calculated due to the length and width measurements on the orthopantomographs are displayed in Table 2. The differences compared to primary correlation are significant at $R, L, W$ 
and $A$ ratios because of specific processes in teeth in cases of pathological attrition. By regression analysis new formulas were developed (Table 3) and the levels of absolute and relative errors were compared (Table 4).

\section{Discussion}

The results depend on the stage of pathological attrition. In the research we have found out that the attrition is caused by bruxism, abnormal occlusion due to dispositioned tooth, and inadequate prosthetic treatment may cause proportional constant intense deposition of tertiary reparative dentine and lowering of occlusal surface depending on pathology stage [12]. However, due to abnormal tooth structures or abrasion factors pathological attrition is not a progressive process during which pulp structures and hard tissues changes depend on time and stage of changes and enhanced process development may take place any time. Also, the better result were established when the mean levels of all six teeth were calculated, and the most distant result were reached when single measurements of mandible canine were included. Improved regressive formulas were checked by new randomized samples of $50 \mathrm{X}$-ray photos of patients with pathological attrition, no information about age was available. The results were ranged by the error not higher than $14 \pm 0.8$ years old.

The further research should be focused on verifying value of tertiary reparative dentine using computer cone beam tomography to determine the dynamics of pulp changes intensity in different stages of disorders that cause pathological attrition. It allows making retrospective analysis, which provides information about average changes of pulp chamber and hard tissues of tooth, so identification of physiological secondary dentine formation before the pathology come about and tertiary reparative dentine formation in pathology development gives a chance to create new regression analysis by two systems coefficients 'before pathology' and 'during pathology development'. Thus all minimal errors occur in techniques of age determination in cases of dental health disorders.

\section{Conclusions}

During the study we used Kvaal et al. age estimation technique for patients with pathological attrition and defined the level of errors which reaches about 47-49\%. Using component regression analysis and Pearson's coefficients we determined the correlation between age results and level of tooth surface attrition and deposition of tertiary reparative dentine due to the kind of pathology, which cause pathological attrition, and the time of pathology. The most significant correlation was found between changes in incisors and lower first premolar. The changes in canine in cases of pathology attrition do not affect the result significantly. Individually calculated modified coefficients in equations by Kvaal et al. age estimation technique in cases of pathological attrition showed the result more adjacent to real age, e.g. the level of absolute error in years was improved from $27 \pm 8.4$ to $13 \pm 0.8$ years.

Age estimation technique can be improved taking into account morphological changes in cases of pathological attrition, and the calculated coefficients allow expanding the circle of person's age that should be defined. Also the examination of two regression systems which stand for attrition of occlusal surface and tertiary reparative dentine deposition in cases of pathology (system 1) and lowering of physiological lever of tooth high as well as deposition of secondary dentine (system 2) exclude the number of errors for accurate age estimation with cone beam tomography.

Table 4. Example of differences of age estimated by means of primary technique of Kvaal et al. and modified technique for patient A with pathological attrition

\begin{tabular}{|c|c|c|c|c|c|}
\hline \multirow[t]{2}{*}{ Teeth/tooth groups } & \multirow[t]{2}{*}{ Age } & \multicolumn{2}{|c|}{$\begin{array}{l}\text { Primary technique of Kvaal } \\
\text { et al. for patients with } \\
\text { pathological attrition }\end{array}$} & \multicolumn{2}{|c|}{$\begin{array}{c}\text { Modified technique of Kvaa } \\
\text { et al. for patients with } \\
\text { pathological attrition }\end{array}$} \\
\hline & & Mean & Difference & Mean & Difference \\
\hline \multirow[t]{2}{*}{ Single tooth } & Actual age & 35 & \multirow{2}{*}{21} & 35 & \multirow{2}{*}{13} \\
\hline & Estimated age & 56 & & 48 & \\
\hline \multirow[t]{2}{*}{ All six teeth } & Actual age & 35 & \multirow{2}{*}{16} & 35 & \multirow{2}{*}{10} \\
\hline & Estimated age & 51 & & 45 & \\
\hline \multirow{2}{*}{$\begin{array}{l}\text { Three maxillary } \\
\text { teeth }\end{array}$} & Actual age & 35 & \multirow{2}{*}{18} & 35 & \multirow{2}{*}{12} \\
\hline & Estimated age & 53 & & 47 & \\
\hline \multirow{2}{*}{$\begin{array}{l}\text { Three mandibular } \\
\text { teeth }\end{array}$} & Actual age & 35 & \multirow{2}{*}{17} & 35 & \multirow{2}{*}{14} \\
\hline & Estimated age & 52 & & 39 & \\
\hline
\end{tabular}




\section{References}

1. Amandeep S. Age estimation from physiological changes of teeth. J Indian Forensic Sci. 2004;6(2): 113-121.

2. Willems G. A review of commonly used dental age estimation techniques. J. Forensic Odontostomatol. 2001;19(1):9-17.

3. Solheim T, Sundnes PK. Dental age estimation of Norwegian adults: a comparison of different methods. Forensic Sci Int. 1980;16(1):7-17.

4. Kostenko Y, Goncharuk-Khomyn M. Possibility of improving method of age determination during pathological attrition. The Journal of forensic odontostomatology. 2013;3:67-68.

5. Gustafson G. Age determination on teeth. J Am Dent Assoc. 1950;41(1):45-54.

6. Bang G, Ramm E. Determination of age in humans from root dentine transparency. Acta Odontol Scand. 1970;28:3-35.

7. Johanson G. Age determination from teeth. Odontol Revy. 1971;22(21 Suppl.):1-126.

8. Maples WR. An improved technique using dental histology for estimation of adult age. J. Forensic Sci. 1978;23(4):764-70.

9. Solheim T. A new method for dental age estimation in adults. Forensic Sci Int. 1993;59:137-47.

10. Kvaal SI, Kolltveit KM, Thompsen IO, Solheim T. Age estimation of adults from dental radiographs. Forensic Sci Int. 1995;74:175-85.

11. Bida VI. Pathological attrition of hard tissue of teeth and main principles of it's treatment. Kyiv: Kyiv truth, Ukraine. 2002.
12. Addy $M$, Shellis RP. Interaction between attrition, abrasion and erosion in tooth wear. Monogr Oral Sci. 2006;20:17-31.

13. Purkait Swapan Kumar. Essentials of Oral Pathology. ISBN 9789350252147. 3rd Edition. 2011;648.

14. Bosmans N, Ann P, Aly M, Willems G. The application of Kvaal's dental age calculation technique on panoramic dental radiographs. Forensic Sci Int. 2005;153:208-12.

15. Landa MI, Garamendi PM, Botella MC, Aleman I. Application of the method of Kvaal et al. to digital orthopantomograms. Int J Legal Med. 2009; 123:123-128.

16. Paewinsky E, Pfeiffer H, Brinkmann B. Quantification of secondary dentine formation from orthopantomograms - a contribution to forensic age estimation methods in adults. Int J Legal Med. 2005; 119:27-30.

17. Sumit S, Upender K, Atul M, Sharma GK. Determination of age from teeth using index value of attrition. J Forensic Med Toxicol. 2013;1:0973-1970.

18. Solheim T. Dental attrition as an indicator of age. Gerodontics. 1988;4:299-304.

19. Solheim T. Amount of secondary dentin as an indicator of age. Scand J Dent Res. 1992;100: 193-9.

20. Morse DR. Age-related changes of the dental pulp complex and their relationship to systemic aging. Oral Surg Oral Med Oral Pathol. 1991;72: 721-45. 